\title{
PENANGANAN PELAKSANAAN BONGKAR MUAT VCM (C2H3CL) DI KAPAL MT. GAS KALIMANTAN LPG CARRIER TYPE-C
}

\author{
Ilham Pratama ${ }^{a}$, Eko Murdiyanto ${ }^{b}$ dan Agus Hadi Purwantomo ${ }^{c}$ \\ ${ }^{\mathrm{a}}$ Taruna (NIT.50134783.N) Program Studi Nautika PIP Semarang \\ ${ }^{b}$ dan Dosen Program Studi Nautika PIP Semarang
}

\begin{abstract}
ABSTRAK
Dalam proses kegiatan bongkar muat khususnya muatan VCM perlu dilaksanakan dengan sebaik-baiknya, hal tersebut memerlukan persiapan yang matang. Pada dasarnya penanganan tersebut bertujuan untuk mengatasi masalah agar dapat diselesaikan dengan baik pada saat pelaksanaan bongkar muat. Permasalahan yang penulis ambil di sini adalah Bagaimana pelaksanaan bongkar muat VCM di kapal MT. Gas Kalimantan? Bagaimana persiapan yang dilakukan dalam pelaksanaan bongkar muat VCM di kapal MT. Gas Kalimantan? Landasan yang digunakan adalah penanganan muatan, yaitu suatu pengetahuan tentang memuat dan membongkar muatan dari dan ke atas kapal agar terwujud lima prinsip pemuatan yang baik. Bongkar muat adalah suatu kegiatan pelayaran memuat ataupun membongkar suatu muatan dari dermaga ke dalam palka atau geladak dari dan ke atas kapal. Dalam penelitian ini menggunakan metode penelitian secara diskriptif kualitatif, yaitu mengumpulkan data-data melalui observasi, dokumentasi dan wawancara.
\end{abstract}

Kata kunci: bongkar muat, tanker LPG/C, suhu, tekanan

\section{ABSTRACT}

In the process of loading and discharging cargo, especially VCM cargo should be carried out in the best. It requires careful preparation good from the ship and shore. Basically handling barriers aims to overcome the problem that can be solved well when loading and unloading process. The problem that the authors take here is How to handling loading and discharging of the vessel MT. Gas Kalimantan? How preparation when loading and unloading in the MT. Gas Kalimantan? Platform used here is the handling cargo is a knowledge of the loading and unloading of ship and upwards so that materialize the five principles of good loading unloading is a load or unload shipping activities of a charge and dock. In this scribd using qualitative descriptive study data download data through observation and interviews.

Keywords: loading and unloading, tanker LPG/C, temperature, pressure

\section{PENDAHULUAN}

Kapal tanker adalah kapal yang dirancang khusus untuk mengangkut minyak bumi atau turunanya dalam bentuk curah. Berdasarkan jenis muatannya kapal tanker dibagi menjadi 3 jenis yaitu oil tanker, chemical tanker, dan gas tanker.
Kapal tanker adalah kapal yang menetapkan standar keselamatan yang paling tinggi mengingat muatan yang dibawanya sangat berbahaya. Sedangkan definisi kapal gas tanker adalah kapal yang dirancang khusus untuk mengangkut gas alam (LNG) atau gas minyak bumi (LPG) yang telah dicairkan (liquified). 
Ilham Pratama, Eko Murdiyanto dan Agus Hadi Purwantomo

Pada umumnya muatan LPG merupakan campuran dari petroleum hydrocarbon yang terdiri dari semata-mata atas propane dan butane. Namun gas-gas kimia hasil ikutan dari industri petroleum seperti amonia hidroksida $(\mathrm{NH})$, vinyl chloride monomer (VCM), ethylene juga diangkut menggunakan kapal ini.

Vinyl chloride monomer (VCM) adalah cairan tak berwarna dengan bau manis khas yang sangat reaktif meski tidak dengan air, dan mungkin berpolimerisasi dengan oksigen, panas, dan cahaya. Uapnya beracun dan mudah terbakar. Karena karakteristik spesifiknya maka diperlukan perhatian khusus selama pelaksanaan bongkar muat.

Minimnya pengetahuan awak kapal tentang bahaya serta penanganan muatan VCM di jenis kapal LPG Carrier type-C / jenis tangki fully pressurized sehingga timbul berbagai hambatan saat proses bongkar muat VCM di kapal MT. Gas Kalimantan. Hambatan yang sering terjadi saat penanganan muatan VCM di MT. Gas Kalimatan yaitu terjadinya kenaikan tekanan tangki secara drastis pada saat proses bongkar muat dan terjadinya kebocoran pada saat pemasangan loading arm/hose dengan manifold yang menjadikan proses bongkar muat menjadi tidak optimal.

Apabila hambatan tersebut tidak segera diatasi maka akan membahayakan pihak darat dan pihak kapal, karena sesuai material safety data sheet, VCM atau dikenal dengan nama 1-chloroethylene, Chloroethene, Ethylene, chloro-, Vinyl chloride monomer merupakan senyawa organic tak jenuh yang memiliki rumus kimia $(\mathrm{C} 2 \mathrm{H} 3 \mathrm{CL})$ yang menjadikan muatan ini mudah bereaksi. VCM memiliki flash point $-108^{\circ}$, berat jenis spesifik 0.9106 , dan titik didih $-13^{\circ} \mathrm{C}$, sehingga muatan ini menghasilkan uap panas yang mudah meledak dan memiliki tekanan tinggi mencapai $17 \mathrm{~kg} / \mathrm{cm} 2$.
Oleh karena itu, penanganan VCM harus memerlukan perhatian dan keterampilan khusus dari awak kapal untuk mengindari hambatan yang terjadi pada saat pelaksanaan bongkar muat VCM sehingga terwujudnya proses bongkar muat yang optimal dan tidak ada suatu hambatan apapun. Sehingga penulis memberikan pandangan penelitian dengan judul "Penanganan Pelaksanaan Bongkar Muat VCM (C2H3CL) di Kapal MT. Gas Kalimantan LPG Carrier Type-C".

Alasan penulis memilih judul penelitian ini adalah karena selama penulis melaksanakan praktek laut penanganan pelaksanaan bongkar muat VCM di kapal MT. Gas Kalimantan seringkali terjadi beberapa kendala ataupun hambatan seperti tekanan tangki yang naik secara drastis pada saat pelaksanaan bongkar muat serta terjadinya kebocoran pada saat pemasangan loading arm / hose sehingga pelaksanaan bongkar muat menjadi kurang optimal serta minimnya pengetahuan crew tentang muatan berbahaya ini menyebabkan penanganan menjadi kurang maksimal.

Pemuatan dan pembongkaran merupakan suatu kegiatan rutin dalam pengoperasian kapal. Pemuatan dan pembongkaran yang benar dan sesuai dengan prosedur adalah suatu yang sangat vital. Untuk itu dibutuhkan pengetahuan dan keterampilan khusus yang harus dimiliki oleh para Mualim dan anak buah kapal yang terlibat langsung dalam kegiatan bongkar muat tersebut.

Hal ini berguna untuk keselamatan yang bersangkutan dan kapal secara keseluruhan juga demi kelancaran operasi kapal. Berdasarkan pengalaman penulis selama melakukan praktek laut (prala) kegiatan bongkar muat terdapat kendala seperti tekanan tangki naik secara drastis dan persiapan persiapan yang harus dilakukan sebelum pelaksanaan bongkar muat yang penulis jadikan pokok permasalahan: 
1. Bagaimana persiapan yang dilakukan dalam pelaksanaan bongkarmuat VCM di kapal MT. Gas Kalimantan?

2. Bagaimana pelaksanaan bongkar muat VCM di kapal MT. Gas Kalimantan?

Suatu kegiatan yang baik dan terarah tentu mempunyai tujuan yang ingin dicapai dan diperoleh. Demikian juga dalam penelitian penelitian ini peneliti mempunyai tujuan yaitu :

1. Untuk mengetahui bagaimana penanganan pelaksanaan bongkar muat VCM di kapal MT. Gas Kalimantan.

2. Untuk mengetahui persiapan yang dilakukan dalam pelaksanaan bongkar muat VCM di kapal MT. Gas Kalimantan.

Adapun manfaat diadakannya penelitian adalah sebagai berikut.

1. Manfaat Teoritis

a. Dapat menambah pengetahuan tentang cara proses bongkar muat muatan VCM dengan studi kasus di lapangan yang mana sangat bermanfaat bagi teman-teman seprofesi dan bagi calon pelaut yang ingin bekerja di atas kapal LPG khususnya kapal LPG carrier type-C dan juga yang masih dalam masa pendidikan dapat digunakan sebagai bahan referensi.

b. Sebagai acuan yang dapat digunakan penelitian lebih lanjut yang berhubungan dengan masalah ini.

2. Manfaat Praktis

a. Kita dapat mempelajari dan melaksanakan cara-cara yang baik dan benar dalam pengetahuan tentang penanganan muatan $V \mathrm{CM}$ di atas kapal jenis LPG carrier type- $C$, sehingga kita dapat bersaing dengan bangsa-bangsa lain dalam pengoprasian bongkar muat VCM di atas kapal sesuai dengan prosedur, sehingga kegiatan bongkar muat menjadi aman dan lancar tanpa ada hambatan-hambatan yang dapat mengganggu kelancaran tersebut.

b. Mengetahui secara langsung kegiatan penanganan muatan VCM dan menambah pengetahuan serta pengalaman awak kapal dalam penanganan muatan gas yang dicairkan dalam tangki yang bertekanan.

Penanganan muatan merupakan suatu istilah dalam kecakapan pelaut (human ship), yang mencakup berbagai aspek tentang bagaimana cara melakukan pemuatan di atas kapal, bagaimana cara melakukan perawatan muatan selama dalam pelayaran, dan bagaimana melakukan pembongkaran di pelabuhan tujuan (stowage).

Untuk itu para perwira kapal dituntut untuk memiliki pengetahuan yang memadai baik secara teori maupun praktek tentang jenis-jenis muatan, perencanaan pemuatan, sifat dan kualitas barang yang akan dimuat, perawatan muatan, penggunaan alat-alat pemuatan, dan ketentuan-ketentuan lain yang menyangkut masalah keselamatan kapal.

Stowage/penatanan muatan merupakan suatu istilah dalam kecakapan pelaut, yaitu pengetahuan tentang memuat dan membongkar muatan dari dan ke atas kapal sedemikian rupa agar terwujud lima prinsip pemuatan yang baik.

Lima prinsip pemuatan yang baik diantaranya adalah melindungi awak kapal dan melindungi buruh, melindungi kapal, melindungi muatan, melakukan muat bongkar secara tepat dan sistematis serta penggunaan ruang muat semaksimal mungkin agar muatan dapat dimuat banyak dan mengurangi kekosongan ruang muat.

Stowage plan adalah sebuah rencana pemuatan yang dibuat atau direncanakan sebelum pemuatan barang, bagi seluruh muatan yang ada di kapal".

Rencana pemuatan di dalam palka kapal, terdapat 2 jenis yaitu "Tentative stowage plan" yang dibuat sebelum barang dimuat 
Ilham Pratama, Eko Murdiyanto dan Agus Hadi Purwantomo

dan "Final stowage plan" yang dibuat setelah selesai memuat.

Bongkar adalah pekerjaan membongkar barang dari atas geladak atau palka kapal dan menempatkan ke atas dermaga atau dalam gudang. Muat adalah pekerjaan memuat barang dari atas dermaga atau dari dalam gudang untuk dapat dimuati di atas kapal sehingga barang dapat dibawa dari satu tempat ke tempat tujuan atau dari pelabuhan satu menuju pelabuhan tujuan sesuai kebutuhan dengan melindungi kapal dan buruh, muatan, melakukan muat bongkar secara tepat dan sisematis.

Bongkar muat adalah suatu kegiatan pelayaran memuat ataupun membongkar suatu muatan dari dermaga, tongkang, truk ke dalam palka atau geladak, dengan menggunakan derek dan katrol kapal maupun darat atau dengan alat bongkar lain, dimana barang yang dipindahkan dari dan ke atas kapal.

Kapal adalah kendaraan air dengan bentuk dan jenis apapun, yang digerakkan dengan tenaga mekanik, tenaga angin atau ditunda, termasuk kendaraan yang berdaya dukung dinamis, kendaraan di bawah permukaan air yang digunakan untuk mengangkut barang dari suatu tempat menuju tempat lain dengan aman dan selamat, serta merupakan alat apung dan bangunan terapung dan tidak berpindahpindah".

Kapal adalah setiap jenis kendaraan air, termasuk kapal tanpa berat benaman dan pesawat terbang laut, yang digunakan atau dapat digunakan sebagai sarana angkutan laut. Kapal dagang dibagi menjadi beberapa kelompok, yaitu:

a. Kapal penumpang, yaitu sebuah kapal yang mengangkut lebih dari 12 penumpang;

b. Kapal barang, yaitu semua kapal jenis kapal tetapi selain kapal penumpang;

c. Kapal tanker, yaitu sebuah kapal yang dirancang atau dirubah untuk mengangkut muatan cair yang dapat terbakar secara alamiah ke dalam tangki. d. Kapal nuklir, yaitu sebuah kapal yang digunakan untuk mengangkut muatan nuklir.

Kapal $L P G$ carrier termasuk dalam kategori kapal tanker pengangkut gas yang dirancang khusus (special design ship), jenis kapal ini digunakan untuk mengangkut muatan gas yang dicairkan secara curah yang disetujui oleh IMO. Beberapa faktor yang diambil dan didasarkan pada efektifitas bagi rancangan kapal gas adalah :

a. Jenis muatan yang dibawa.

b. Kondisi muatan yang dibawa (bertekanan penuh, semi bertekanan, berpendingin penuh).

c. Jenis perdagangan dan penanganan yang fleksibel oleh kapal.

d. Tersedianya fasilitas terminal pada saat pemuatan atau pembongkaran.

Semi Pressurised Ship (kapal dengan tangki semi bertekanan) adalah kapal jenis ini hampir memiliki persamaan dengan kapal dengan tangki bertekanan, untuk jenis tangki semi bertekanan, tangki dirancang menggunakan pembatas-pembatas kedua (kapasitas muatan dapat diubah-ubah dari $2.000 \mathrm{~m}^{3}$ sampai $15.000 \mathrm{~m}^{3}$ terkadang beberapa kapal dapat memuat untuk menahan muatan dengan tekanan antara 5-7 bar dan bersuhu $-33^{\circ} \mathrm{C}$. Apabila dibandingkan dengan kapal dengan bertekanan penuh. Pengurangan ketebalan tersebut dimaksudkan agar dapat memuat muatan lebih banyak dan beragam, tetapi tetap tidak mengurangi unsur keselamatan di atas kapal. Jenis muatan yang dapat diangkut ke dalam jenis tangki ini adalah LPG, vinly klorida, propilyne, butadine. 


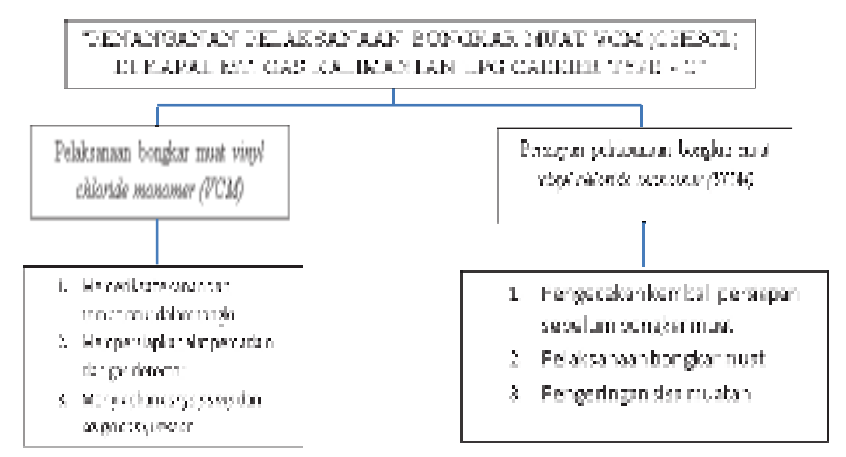

\section{METODOLOGI}

Kata metodologi berasal dari penggabungan dua kata yang berasal dari Yunani, yaitu metodos dan logos. Metodos berarti melalui dan logos berarti ilmu pengetahuan. Metode merupakan suatu kerangka kerja untuk melakukan suatu tindakan atau suatu kerangka berfikir untuk menyusun suatu gagasan yang beraturan, berarah dan berkonteks dengan maksud dan tujuan.

Metode penelitian adalah cara atau teknis yang dilakukan dalam penelitian, apakah pendekatan metode kualitatif, metode kuantitatif atau hazop, atau yang lainnya. Dan yang digunakan oleh peneliti di dalam pembahasan penelitian adalah deskriptif kualitatif untuk menggambarkan dan menguraikan objek yang diteliti. Metode ini dilakukan dengan cara mengumpulkan data yang telah diperoleh dan dianalisa untuk dihubungkan dengan teori-teori yang ada untuk diambil kesimpulan yang logis. Permasalahan yang terjadi diuraikan, dipaparkan dan diidentifikasi penyebabnya, kemudian dianalisa pemecahan masalahnya.

Metode penelitian pada dasarnya merupakan cara ilmiah untuk mendapatkan data dengan tujuan dan kegunaan tertentu..

1. Metode deskriptif

Metode penelitian deskriptif adalah metode penelitian yang dilakukan untuk mengetahui nilai variabel mandiri atau lebih (independen) tanpa membuat perbandingan atau menggabungkan antara variabel satu dengan yang lain.
2. Metode kualitatif

Metode penelitian kualitatif adalah metode penelitian yang berlandaskan pada filsafat postpositivisme, digunakan untuk meneliti pada kondisi objek yang alamiah, (sebagai lawannya adalah eksperimen) dimana peneliti adalah sebagai instrumen kunci, teknik pengumpulan data dilakukan secara triangulasi (gabungan), analisis data bersifat induktif/kualitatif, dan hasil penelitian lebih menekankan makna generalisasi.

Oleh karena itu di dalam pembahasan nanti peneliti berusaha memaparkan hasil dari semua studi dan penelitian mengenai suatu objek yang diperoleh, baik hal-hal yang bersifat teori juga memuat hal-hal yang bersifat praktis, dalam artian bahwa selain ditulis dari beberapa literatur buku, juga bersumber dari objek-objek penelitian yang juga terdapat dalam buku kemaritiman. Penggunaan aspek observasi atau pengamatan sangat berperan dalam penelitian ini. Yang nantinya hasil observasi atau pengamatan di atas kapal yang dilakukan oleh peneliti akan digabungkan dengan sumber data yang lain seperti, hasil wawancara dan dokumentasi di atas kapal selama peneliti melakukan penelitian sehingga mencapai hasil yang maksimal sesuai dengan yang peneliti harapkan.

Tempat penelitian yang digunakan penulis dalam mengadakan pengamatan adalah di kapal MT. Gas Kalimantan yang merupakan salah satu kapal LPGcarrier milik PT. Berlian Laju Tanker Tbk. Kapal MT. Gas Kalimantan merupakan jenis kapal tanker gas LPG tipe-C yang digunakan untuk mengangkut muatan gas yang dicairkan seperti mix propane dan butane, Vinyl Chloride Monomer (VCM), butadiene, C4 Vinyl Chloride Monomer $(V C M)$. Kapal MT. Gas Kalimantan adalah objek kapal dimana penulis melakukan praktek laut dan tempat penulis melakukan penelitian. Selama melakukan praktek laut 
Ilham Pratama, Eko Murdiyanto dan Agus Hadi Purwantomo

banyak permasalahan yang terjadi dalam penanganan muatan, karena itu dalam penelitian ini penulis membahas tentang optimalisasi pembongkaran dan pemuatan Vinyl Chloride Monomer (VCM) di kapal MT. Gas Kalimantan periode September 2015 sampai Oktober 2016.

Data adalah suatu informasi yang digunakan dalam suatu penelitian agar dapat dilakukan pembahasan. Data yang diperoleh dengan analisis. Berdasarkan cara memperolehnya, data yang diperoleh selama penelitian sebagai pendukung tersusunnya penulisan ini diantaranya.

1. Data primer

Data primer adalah data yang diperoleh langsung dari informan. Yang termasuk data primer adalah transkip hasil wawancara dan hasil temuantemuan lain saat proses pelaksanaan penelitian. Dalam hal ini penulis mendapatkan data berdasarkan pengalaman, pengamatan, dan dokumentasi penulis saat melaksanakan prosedur passage planning dan transit di Suez Canal. Pada sumber data primer ini penulis akan menggunakan metode wawancara. Wawancara ditujukan kepada Master, Chief Officer, dan Second Officer yang pernah bertemu dengan peneliti di kapal.

2. Data sekunder

Data sekunder adalah data yang diperoleh dari teknik pengumpulan data yang menunjang data primer yang bersumber dari buku, jurnal, laporan tahunan, literature dan dokumen lain yang berhubungan dengan masalah penelitian. Data sekunder juga bisa berupa data yang tidak langsung seperti dokumen-dokumen kapal yang akan membantu penelitian yang dilakukan oleh peneliti.

Dalam penelitian ini, peneliti menggunakan beberapa metode pengumpulan data, diantaranya adalah sebagai berikut:
1. Riset Lapangan

a. Wawancara

Wawancara ditujukan kepada Master, Chief Officer, dan Second Officer di kapal MT. Gas Kalimantan. Wawancara dilakukan dengan menggunakan pedoman wawancara yang telah dibuat oleh peneliti. Pertanyaan yang telah dibuat oleh peneliti dalam pedoman wawancara dapat dikembangkan sesuai dengan kebutuhan informasi yang diperlukan saat wawancara sehingga wawancara dapat berjalan dengan terbuka namun tetap fokus pada masalah penelitian. Dari wawancara tersebut, peneliti berhasil mendapatkan data dan informasi yang dibutuhkan dalam penelitan.

b. Observasi

Metode yang peneliti lakukan berdasarkan pada pengalaman selama melaksanakan Proyek Laut di atas kapal MT. Gas Kalimantan selama 13 bulan 10 hari. Sehingga peneliti dapat melihat dan mengalami secara langsung pelaksanaan proses passage planning dan transit berlangsung. Observasi nonpartisipan (nonparticipant observation) pengamat tidak ikut serta dalam kegiatan, dia hanya berperan mengamati kejadian, tidak ikut dalam kegiatan.

c. Dokumentasi

Metode dokumentasi ini sebagai pelengkap dari penelitian suatu penelitian, metode ini peneliti laksanakan dengan cara melihat semua dokumen-dokumen yang berhubungan dengan masalah yang dibahas dalam penelitian ini, serta pengambilan audio visual melalui media elektronik saat pelaksanaan proses passage 
planning dan transit sedang berlangsung.

2. Metode Kepustakan

Tinjauan pustaka adalah cara mencari data suatu penelitian yang memerlukan bahan yang bersumber dari perpustakaan. Riset kepustakaan juga disebut suatu sistem pengumpulan data dengan mencari sumber dalam berbagai buku mengenai keterangan-keterangan yang dibahas dalam penelitian. Begitu juga dengan penelitian, selain melaksanakan riset lapangan juga melaksanakan riset kepustakaan guna mendapatkan keterangan yang akurat mengenai masalah yang akan dibahas. Riset penelitian itu peneliti laksanakan dengan jalan mengumpulkan buku-buku yang berkenaan dengan olah gerak kapal sewaktu praktek di atas kapal dan yang ada di dalam perpustakaan PIP Semarang.

Analisis data adalah upaya yang dilakukan dengan jalan bekerja dengan data, mengorganisasikan data, memilahmilahnya menjadi satuan yang dapat dikelola, mensintesiskannya, mencari dan menemukan pola, menemukan apa yang penting dan apa yang dipelajari, dan memutuskan apa yang dapat diceritakan pada orang lain.

Proses analisis data dimulai dengan menelaah seluruh data yang tersedia dari berbagai sumber, yaitu dari wawancara, pengamatan yang sudah dituliskan dalam caatan lapangan, dokumen pribadi, dokumen resmi, gambar, foto, dan sebagainya. Adapun teknik analisis data yang digunakan dalam penelitian ini adalah sebagai berikut.

1. Pengumpulan Data

Dalam penelitan ini pengumpulan data dilakukan dengan mencari, mencatat, dan mengumpulkan data melalui hasil wawancara, observasi, dan dokumentasi.
2. Penyajian Data

Setelah data direduksi, maka langkah selanjutnya adalah menyajikan data. Dalam penyajian data, maka data terorganisasikan dan tersusun dalam pola hubungan, sehingga akan semakin mudah dipahami. Display data, maka akan memudahkan untuk memahami apa yang terjadi, merencanakan kerja selanjutnya berdasarkan apa yang telah dipahami tersebut. Penyajian data dilakukan untuk mempermudah peneliti untuk dapat mendeskripsikan data sehingga akan lebih mudah dipahami mengenai kebijakan mengenai prosedur pembuatan passage planning untuk Suez Canal yang diteliti.

3. Kesimpulan dan Verifikasi

Tahap selanjutnya adalah penarikan kesimpulan dan verifikasi. Kesimpulan awal yang dikemukakan masih bersifat sementara, dan akan berubah bila tidak ditemukan buktibukti yang kuat yang mendukung pada tahap pengumpulan data berikutnya. Pada penelitian ini, kesimpulan awal yang dikemukakan oleh peneliti akan didukung oleh data-data yang diperoleh peneliti di lapangan. Jawaban dari hasil penelitian akan memberikan penjelasan dan simpulan atas permasalahan penelitian yang diteliti dalam penelitian ini.

\section{HASIL PENELITIAN \& PEMBAHASAN}

Persiapan pelaksanaan bongkar muat VCM di kapal MT. Gas Kalimantan dilakukan sesuai prosedur yang berlaku.

a. Persiapan pelaksanaan muat VCM di kapal MT. Gas Kalimantan

1) Memeriksa temperatur dan tekanan yang ada di dalam tangki.

Suhu tangki pada saat sebelum terjadi kenaikan suhu secara drastis 
Ilham Pratama, Eko Murdiyanto dan Agus Hadi Purwantomo

yaitu $20^{\circ} \mathrm{C}$ dengan tekanan tangki 10,3 bar, meskipun kenaikan suhu tersebut belum mencapai batas maksimum yang diizinkan, namun telah terjadi kenaikan suhu cukup drastis yang berarti tekanan dalam tangki juga naik. Pada saat kejadian seperti itu harus diambil tindakan untuk menurunkan suhu dalam tangki muatan, dengan tujuan mencegah terjadinya kenaikan suhu maksimum tidak melebihi $45^{\circ} \mathrm{C}$, kenaikan suhu yang terlalu besar perbedaannya dibandingkan suhu sebelum pemuatan, sehingga menyebabkan bertambahnya volume muatan di dalam tangki kapal, hal ini menjadi masalah bila tangki muatan tidak lagi mempunyai ruangan untuk menampung penambahan volume tadi (over limit).

Dalam kondisi normal saat pemuatan penuh, kondisi muatan mempunyai tekanan $5 \mathrm{~kg} / \mathrm{cm}^{2}$ dan suhu dalam tangki $21^{\circ} \mathrm{C}$, sebelum pemuatan itu berlangsung Mualim I selalu memberikan cargo stowage plan dimana Mualim I merencanakan pemuatan, didalamnya terdapat batas maksimum tekanan dan suhu, untuk itu saat penanganan muatan tersebut Mualim jaga harus tetap menjaga kondisi tersebut agar tetap stabil agar tekanan dan suhu tidak naik. Meskipun di atas kapal terdapat safety relief valve apabila sampai terbuka maka alarm muatan akan berbunyi dan yang terjadi semua keran akan menutup dan operasi muat bongkar pun akan berhenti, maka tekanan di dalam sambungan pipa akan bertambah dan bisa menyebabkan ledakan dalam sambungan pipa. Jadi, pada saat pengoperasian muatan sebaiknya sesering mungkin mengecek tekanan pada tangki, terutama saat proses pemuatan yang berlangsung pada siang hari dan memperhatikan kenaikan tekanan ESD indikator batas kerjanya tidak boleh melebihi 30 $\mathrm{kg} / \mathrm{cm}^{2}$. Pengecekan ini dilaksanakan minimal 15 menit sekali. Apabila ada hal-hal yang tidak semestinya selama pengawasan segera laporkan kepada perwira jaga atau langsung laporkan kepada Mualim I untuk menangani masalah yang terjadi agar tidak terjadi hal-hal yang tidak diinginkan pada saat melaksanakan proses muat (loading).

Terjadinya kenaikan tekanan tangki secara drastis yang mengakibatkan diturunkannya kecepatan memuat rata-rata (rate) per jam oleh pihak terminal atas rekomendasi dari Mualim I dan Nakhoda. Hal tersebut merupakan jalan terakhir yang diambil oleh Mualim I karena tidak bekerjanya cooling spray water yang merupakan salah satu sarana untuk mendinginkan tangki ketika memuat. Karena penurunan rate tersebut menjadikan proses memuat tidak sesuai dengan instruksi dari ship charter dan perusahaan. Pada saat itu rate ratarata diturunkan menjadi 96.67 MT/ jam yang sesuai instruksi adalah 200 MT/ jam, sehingga proses memuat membutuhkan waktu 15 jam 55 menit. Apabila rate dinaikkan menjadi $200 \mathrm{MT} /$ jam maka tekanan dan suhu dalam tangki juga naik dengan drastis yang akan membahayakan kapal dan terminal. Hal ini menjadikan pelaksanaan memuat menjadi lama atau delay yang mengakibatkan pihak pencharter dan perusahaan rugi.

2) Menyiapkan alat pemadam dan gas detector.

Alat-alat pemadam harus segera disiapkan sebelum pelaksanaan pemuatan dan segera di standby kan di sekitar manifold agar jika terjadi 
kebakaran pada sambungan manifold dan loading arm/cargo hose dapat segera diatasi. Gas detector disiapkan untuk mengecek jika ada terjadi kebocoran dan harus selalu di kalibrasi agar penunjukannya menjadi tepat.

3) Menyiapkan cargo compressor.

Cara menggunakan compressor bervariasi dalam menurunkan tekanan dalam tangki karena dari Mualim I mempunyai cara yang berbeda-beda. Di kapal MT. Gas Kalimantan cargo compressor digunakan oleh Mualim I untuk mendorong muatan gas agar tekanan turun dengan mensirkulasi muatan, yaitu dengan menghisap muatan gas dari tangki yang dimuat dan didorong ke dalam tangki yang belum dimuat melalui saluran muatan uap atau sebaliknya, tangki yang bermuatan uap itu kembali dibuka dan didorong dengan kompresor ke dalam tangki yang sudah dimuat tetapi dengan membuka bypass, jadi muatan cair bercampur dengan muatan uap, karena muatan cair dingin bercampur dengan muatan uap maka muatan uap pun akan menjadi cair.

Untuk compressor di kapal MT. Gas Kalimantan temperatur kerjanya tidak boleh melebihi suhu $45^{\circ} \mathrm{C}$ kalau terjadi di atas itu maka seluruh operasional bongkar muat akan mati dan semua keran hydraulik akan menutup, bertujuan agar compressor tidak meledak bila terjadi suhu yang berlebihan. Maka dibutuhkan pendingin bagi compressor, yaitu dengan cooling sea water.

Umumnya pendingin yang digunakan pada cargo kompressor untuk jenis kompressor kapal pengangkut gas bertekanan tinggi adalah menggunakan air laut. Air laut yang dingin akan mengatur panas kompressor agar suhunya tetap stabil (Specialised Tanker Training
Progamme Liquified Gas, Warsash Maritime Centre, 2002:56).

b. Persiapan pelaksanaan bongkar VCM di kapal MT. Gas Kalimantan

1) Memeriksa temperatur dan tekanan yang ada di dalam tangki.

Pemeriksaan temperatur dan tekanan dilakukan untuk mengetahui adanya sisa muatan dalam tangki yang biasanya dalam bentuk vapour. Pemeriksaan temperatur dan tekanan dilakukan juga agar pada saat pelaksanaan pembongkaran temperatur dan tekanan tidak naik tinggi. Hal ini sering terjadi pada saat bongkar. Mengenai kenaikan tekanan tangki yang drastis saat pembongkaran Mualim I mengemukakan bahwa tindakan yang dilakukan untuk mengatasi kenaikan tekanan tangki dengan cara menggunakan cargo compressor, vapour return line, water spray line dan cargo spray line.

Menurut McGuire and White dalam bukunya Liquefied Gas Handling Principles On Ships And In Terminals (2000:116), "in the LPG trade they are becoming more common but are usually connected to the ship for safety reasons and might only be operated if high shipboard pressures become difficult contain."

Terjemahan bebas:

"Penggunaan vapour return adalah cara yang paling sering digunakan di kapal $L P G$ Carrier untuk tujuan keselamatan ketika tekanan yang ada di dalam tangki tinggi yang mengakibatkan tangki menjadi susah untuk dimuati. Vapour return ini bekerja dengan cara mengalirkan vapour dari kapal menuju ke tangki darat dan kembali lagi ke tangki kapal."

Apabila tekanan tangki di kapal lebih tinggi dari tekanan tangki di darat, maka gas muatan di tangki 
Ilham Pratama, Eko Murdiyanto dan Agus Hadi Purwantomo

kapal akan dialirkan kembali ke tangki darat hingga kedua tangki tersebut memiliki tekanan yang sama. Sesuai prinsip utamanya adalah dengan menyamakan tekanan antara tangki di darat dan di kapal.

Dengan membuka keran saluran vapour kapal yang telah terpasang dengan saluran vapour darat, vapour yang berada di tangki muatan secara otomatis akan mengalir dengan sendirinya karena perbedaan tekanan di tangki kapal dan di tangki darat.

2) Menyiapkan alat pemadam dan gas detector.

Alat-alat pemadam harus segera disiapkan sebelum pelaksanaan pemuatan dan segera di stand by kan di sekitar manifold agar jika terjadi kebakaran pada sambungan manifold dan loading arm/cargo hose dapat segera diatasi. Gas detector disiapkan untuk mengecek jika ada terjadi kebocoran dan harus selalu dikalibrasi agar penunjukannya menjadi tepat.

3) Menyiapkan cargo compressor.

Cargo compressor disiapkan untuk pengeringan sisa muatan yang berada di cargo line agar semua muatan di cargo line bersih dan tidak ada sisa dengan cara didorong menuju tangki darat pada proses pembongkaran. Cargo compressor juga digunakan jika tekanan tangki naik secara drastis maka cargo compressor digunakan untuk menurunkan suhu dan tekanan tangki yang tinggi dengan sirkulasi yang mengubah vapour menjadi liquid dan tekanan tangki dan temperatur tangki akan turun secara perlahan. Kompressor harus memiliki sistem relief valve pembuangan tekanan. Untuk jenis kapal LPG fully pressurized, dengan sistem tekanan tertinggi adalah 250-265 psig (17.2 18.3 bar gauge). (Balckmer, Liquified Gas Handbook, 2001:10).
Karena kompressor juga memiliki sistem safety relief valve setting yang langsung berhubungan dengan ESD dan langsung aktif apabila tekanan melebihi batas yang telah ditentukan yang akan mengakibatkan semua keran hidrolik tertutup dan mengakibatkan matinya kargo kompressor.

4) Menyiapkan cargo pump

Pompa kargo disiapkan sebelum pelaksanaan pembongkaran yaitu dicek minyak hidrolik pada pompa kargo jika minyak hidrolik pada pompa kargo kurang atau habis segera laporkan pada Mualim I dan Mualim I akan memberitahukan kepada Masinis I untuk mengisi minyak hidroliknya. Pastikan koordinasi dengan kamar mesin untuk mengoperasikan pompa kargo.

5) Memastikan emergency shut down berfungsi dengan baik.

Emergency shut down harus di cek bekerja dengan baik atau tidak sebab emergency shut down sangat penting fungsinya ketika pelaksanaan pembongkaran muatan. Ketika terjadi keadaan darurat pada saat pelaksanaan pembongkaran emergency shut down harus dapat berfungsi dengan baik untuk segera mungkin menghentikan kegiatan pembongkaran karna terlalu lama jika kita harus mematikan pompa kargo dan menutup semua valve. Ketika emergency shut down di tekan maka secara otomatis pompa kargo akan berhenti dan ESD valve akan menutup secara otomatis.

c. Penanganan bongkar muat vinyl chloride monomer di kapal MT. Gas Kalimantan

Cara penanganan muatan vinyl chloride monomer yang dilakukan berdasarkan prosedur manual adalah:

a. Pelaksanaan pemuatan vinyl chloride monomer di MT. Gas Kalimantan: 
1) Perencanaan operasi

Sebelum melaksanakan kegiatan muat haruslah diadakan safety meeting yang dilaksanakan oleh: Master, Chief Officer, Chief Engineer, Bosun, serta untuk membahas mengenai perencanaan pemuatan dan keselamatan kerja.

2) Kapal sandar dan terikat

Setelah kapal sandar dan terikat selanjutnya yang dilakukan adalah menyiapkan gang way (tangga) serta jaring-jaring.

3) Menghubungkan loading arm/hose dengan pipa manifold.

a) Pastikan sambungan manifold dengan loading arm/hose terpasang dengan baik dan dilakukan tes kebocoran.

b) Setelah terhubung maka lakukan vapour return untuk menyamakan tekanan tangki darat dengan tekanan tangki di kapal.

4) Pengaturan pipa

Mualim I berada di CCR (Cargo Control Room) melakukan pengecekan terhadap pengaktifan ESD serta high level alarm sedangkan $A B$ (able seamen) mengecek dan meyakinkan bahwa pipa telah bekerja dengan benar.

5) Mulai pemuatan

Setelah semua dalam keadan siap maka dapat dimulai transfer muatan dengan rate yang rendah, dan hidupkan compressor untuk mengirim vapour kapal ke darat hal ini bertujuan agar tekanan tangki tetap stabil. Hal-hal yang perlu diperhatikan dan diperiksa ketika pemuatan sedang berlangsung:

a) Tekanan manifold dan aliran / liquid rate di manifold.

b) Tekanan tangki, suhu muatan dan level muatan.

c) Ketika terjadi kenaikan suhu/tekanan yang signifikan, maka lakukan tindakan segera untuk menurunkan suhu/tekanan tersebut.

d) Jika kompressor kargo digunakan maka periksa suhu dan tekanannya secara rutin.

e) Jumlah muatan yang sudah masuk ke dalam tangki tiap jam.

f) Trim, list, movement / pergerakan kapal (maju atau mundur) tinggal mengatur tross dan spring line.

6) Selesai memuat

Setelah pemuatan telah sesuai dengan hasil meeting maka lakukan topping up dan mematikan cargo compressor, pemberitahuan ke darat 1 jam sebelum dilakukan penurunan rate pemuatan.

7) Pengeringan sisa muatan menggunakan vapour

Proses ini bertujuan untuk mengeringkan sisa liquid yang tertinggal pada pipa muatan saat pemuatan, sisa muatan dikeringkan dengan menggunakan vapour dari darat. Sisa liquid yang ada di dalam pipa akan didorong oleh tekanan vapour yang tinggi.

8) Pelepasan loading arm /hose

Pelepasan loading arm (lengan muat) / hose merupakan tanda bahwa pemuatan telah selesai yang diawali dengan pelepasan lengan muat cargo dan kemudian disusul dengan lengan muat vapour di manifold.

b. Pelaksanaan pembongkaran vinyl chloride monomer di MT. Gas Kalimantan

Pada tahap ini lebih banyak hal yang harus dipersiapkan dan diperhatikan, karena cairan yang berada di atas kapal harus kita bongkar menggunakan pompa muatan yang berasal dari kapal kita 
Ilham Pratama, Eko Murdiyanto dan Agus Hadi Purwantomo

sendiri. Dalam pelaksanaan pembongkaran harus memperhatikan hal-hal berikut:

1) Pelaksanaan setelah sandar

a) Hubungkan bounding wire

Bounding wire adalah kawat penghubung antara kapal dengan darat yang digunakan sebagai arde yang berfungsi untuk menghindari tegangantegangan listrik statis saat proses bongkar muat.

b) Siapkan tangga

c) Melaksanakan ceking kapal atau darat

d) Rapat sebelum bongkar

2) Menghubungkan loading arm/hose

a) Pastikan penggunaan packing sesuai dengan karakteristik muatan dan setelah semua loading arm/hose selesai dihubungkan, maka lakukan pressure test (cek kebocoran) dengan vapour dari darat menggunakan air sabun.

b) Setelah terhubung maka lakukan vapour return untuk menyamakan tekanan tangki darat dengan tekanan tangki di kapal.

3) Mulai pembongkaran

a) Setelah selesai mempersiapkan pipa-pipa untuk bongkar, maka pompa muat bisa dihidupkan untuk bongkar dengan aliran yang rendah, setelah itu naikkan rate perlahan sesuai persetujuan.

b) Pengisian air balast harus dimulai setelah memulai pembongkaran dengan rate yang rendah.

4) Selesai Pembongkaran

a) Beritahu darat atau terminal 1 jam sebelum akan dilakukan penurunan rate kepada loading master. b) Setelah loading rate diturunkan, maka hal selanjutnya yang dilaksanakan adalah menghabiskan sisa muatan secara teliti.

c) Konfirmasi ke terminal bahwa pompa terakhir akan dimatikan.

d) Setelah pompa kargo dimatikan, hal selanjutnya adalah menghabiskan sisa muatan yang ada di dalam pipapipa liquid.

5) Pengeringan sisa muatan di dalam pipa liquid menggunakan vapour

a) Gunakan cargo compressor untuk mendorong sisa liquid menggunakan vapour.

b) Laksanakan pengeringan pada lengan vapour dan lengan cargo di manifold hingga campuran hydrocarbon tidak kurang dari $1 \%$ pada saat membersihkan valves.

c) Setelah pengeringan sisa muatan selesai maka tutup semua keran.

6) Pelepasan loading arm/hoses

Pastikan pada saat pelepasan loading arm/hoses tidak ada tekanan yang tersisa, karena apabila masih ada tekanan akan sangat bahaya pada saat pelepasan, sisa vapour akan menyembur. Apabila tekanan di manifold sudah menunjukkan angka nol, barulah pelepasan loading arm/hoses dilakukan.

Berdasarkan wawancara dengan Mualim I, prosedur penanganan bongkar muat vinyl chloride monomer di kapal MT. Gas Kalimantan adalah atas berdasarkan perintah Nakhoda dan Mualim I dan sesuai instruksi dari perusahaan pemilik kapal yang bersangkutan. Pada awal dan selama penanganan muatan harus dilakukan pemeriksaan oleh 
petugas yang bertanggung jawab untuk memastikan bahwa muatan hanya memasuki atau meninggalkan tangki muatan yang ditunjuk dan muatan tidak keluar atau bocor ke compressor room atau ruangan instalansi lainnya. Perwira jaga di atas kapal dan petugas terminal juga harus memeriksa tekanan pipa dan selang manifold dalam perkiraan selesainya pemuatan atau pembongkaran. Setiap penurunan atau perbedaan tekanan yang ditandai antara tekanan kapal dan terminal ini dapat menunjukkan bahwa pipa atau selang tersebut bocor dan mengharuskan pengoperasian muatan dihentikan sampai penanganan kebocoran selesai dilaksanakan.

Cara penanganan bongkar muat tersebut semua adalah demi kelancaran operasi agar proses bongkar muat vinyl chloride monomer optimal. Oleh karena itu prosedur yang berlaku harus dijalankan dengan sebaik-baiknya.

\section{KESIMPULAN \& SARAN}

\section{A. Kesimpulan}

Berdasarkan pembahasan, maka dengan ini penulis meringkas suatu kesimpulan yang diambil dari analisa masalah adalah sebagai berikut :

a. Penanganan pelaksanaan bongkar muat vinyl chloride monomer di kapal MT. Gas Kalimantan harus sesuai dengan tahapan-tahapan yang ada dimulai dari perencanaan operasi yang meliputi menyiapkan semua peralatan pelaksanaan bongkar muat serta peralatan keselamatan dan menyiapkan line up pipa cargo, dilanjutkan dengan pelaksanaan bongkar muat dan hal-hal yang harus diperhatikan selama pelaksanaan bongkar muat yaitu tekanan manifold dan liquid rate di manifold serta tekanan tangki dan suhu muatan jika terjadi kenaikan secara signifikan segera menurunkan suhu dan tekanan dengan menggunakan kompressor cargo dan setelah selesai dengan proses bongkar muat selanjutnya melakukan pengeringan sisa muatan yang berada di pipa muat dengan menggunakan vapour yang tekanannya tinggi.

b. Persiapan yang harus dilakukan dalam pelaksanaan bongkar muat vinyl chloride monomer di atas kapal MT. Gas Kalimantan dimulai dari memeriksa suhu dan tekanan dalam tangki selanjutnya menyiapkan alat pemadam dan gas detektor untuk menjaga keselamatan saat pelaksanaan bongkar muat serta menyiapkan kompressor kargo guna menurunkan tekanan dan suhu tangki jika dalam pelaksanaan bongkar muat suhu dan tekanan tangki naik secara signifikan dan pompa kargo disiapkan dicek minyak pelumas serta perhatikan suhu pompa saat sedang bekerja.

\section{B. Saran}

Berikut adalah saran-saran yang diambil penulis agar pelaksanaan bongkar muat vinyl chloride monomer menjadi optimal, yaitu:.

a. Untuk mengoptimalkan proses bongkar muat vinyl chloride monomer di kapal MT. Gas Kalimantan, maka disarankan untuk selalu melaksanakan dan meningkatkan prosedur manual yang berlaku.

b. Kenaikan suhu dan tekanan tangki muatan secara signifikan pada saat pelaksanaan bongkar muat berlangsung harus diperhatikan karna dapat menghambat proses bongkar muat. 
Ilham Pratama, Eko Murdiyanto dan Agus Hadi Purwantomo

\section{DAFTAR PUSTAKA}

Gianto, Herry dan Arso Martopo. 2004. Pengoperasian Pelabuhan Laut. Semarang: BPLP

New IGC Code. 2014. Amandment To The International Code For The Construction And Equipment of Ships Carrying Liquefied Gases In Bulk. Greece: Athens

IMO. 2004. Safety Life At Sea Consolidated Edition. London: International Maritime Organization

Martopo, Arso. 2001. Penanganan Muatan. Semarang: Badan Penerbit Buku Maritim

Tim Penyusun. 2014. Muatan Berbahaya. Semarang: Politeknik Ilmu Pelayaran Semarang

McGuire and White. 2000. SIGTTOLiquefied Gas Handling Principles On Ships and in Terminals. England: Witherby Co Ltd

Moleong, Lexy J. 2004. Metodologi Penelitian Kualitatif. Bandung: PT. Remaja Rosdakarya

Pemerintah RI. 2008. Undang-Undang Pelayaran No. 17, 2008. Jakarta: Sinar Grafika

Tim Penyusun. 2014. Muatan Berbahaya. Semarang: Politeknik Ilmu Pelayaran Semarang

Jonatan, Sarwono. 2013. Metode Penelitian Kuantitatif dan Kualitatif. Yogyakarta: Graha Ilmu 